\title{
Dynamic Changes of Betatrophin and Its Potential Effect on $\beta$-cells in Spontaneously Developed or Streptozocin-induced Diabetes Monkeys
}

\author{
Yongqiang Liu', Xiaoli Wang1, Bingdi Wang1, Guofeng Sun', Francine Gregoire², Keefe Chng², Jinhu Wang ${ }^{3}$, Yixin (Jim) \\ Wang $^{1,2}$ and Yong-Fu Xiao ${ }^{1 *}$
}

${ }^{1}$ Cardiovascular and Metabolic Diseases Research, Crown Bioscience Inc., 6 Beijing West Road, Science \& Technology Park, Taicang Economic Development Area, Taicang, Jiangsu Province 215400, P.R. China

2International Institute of Biomedical Research (IIBR), a Crown Bioscience Company at David H. Murdock Research Institute (DHMRI), Kannapolis, NC, USA

${ }^{3}$ Department of Laboratory Medicine, Taicang Affiliated Hospital of Soochow University, Taicang, China

\begin{abstract}
Effects of betatrophin on $\beta$-cell proliferation and insulin secretion have been reported controversially in rodent studies. This study was to investigate the dynamic changes of betatrophin and its potential effect on $\beta$-cell function in non-human primates (NHPs). Blood betatrophin levels in naturally developed diabetes cynomolgus monkeys $(n=65)$ significantly correlated with their body weights and blood glucose levels in the females $(n=20)$ and with insulin and $C$-peptide levels in the males $(n=45)$. Liver expression of betatrophin mRNA was markedly higher in spontaneously developed diabetes monkeys than in normoglycemic ones. Its liver expression correlated well with islet size and insulin content in normoglycemic cynomolgus monkeys and also well in spontaneously hyperglycemic (>200 mg/ $\mathrm{dL}$ ) cynomolgus monkeys with high blood insulin level, but not well in those with very low blood insulin content. Both blood glucose and betatrophin increased dramatically in normoglycemic rhesus monkeys $(n=7)$ after streptozocin (STZ) administration. Blood insulin initially increased on day 1 after STZ dosing and then decreased dramatically. Two NHPs with blood glucose back to $\sim 80 \mathrm{mg} / \mathrm{mL}$ on day 14 after STZ injection showed recovery of insulin secretion. In another two STZ-treated NHPs with blood glucose $>250 \mathrm{mg} / \mathrm{dL}$, apparent proliferation of both $\beta$-cells and non- $\beta$ cells was observed in their islets. The rest NHPs with more completed $\beta$-cell destruction after STZ dosing showed much higher blood glucose $(>300 \mathrm{mg} / \mathrm{dL}$ ) with very low insulin and no obvious $\beta$-cell proliferation. Our results indicate that NHP liver expresses abundant betatrophin mRNA. As its levels correlated well with islet size and insulin content in some diabetic NHPs, it might play a role in $\beta$-cell proliferation. Our data are consistent with the clinical finding of the elevation of circulating betatrophin in patients with type 2 diabetes. In addition, betatrophin-enhanced $\beta$-cell proliferation seems requiring a minimal base level of pancreatic $\beta$-cells and islets.
\end{abstract}

Keywords: Betatrophin; $\beta$-cell; Insulin; Streptozocin; Nonhuman primate

\section{Introduction}

Diabetes results from dysfunctional carbohydrate metabolism due to a relative deficiency of insulin. The world prevalence of diabetes among adults (aged 20-79 years) was 6.4\%, affecting 285 million adults, in 2010, and will increase to $7.7 \%$ and 439 million adults by 2030 . Between 2010 and 2030, there will be a $69 \%$ increase in numbers of adults with diabetes in developing countries and a $20 \%$ increase in developed countries [1]. It has become a major threat to human health.

Though diabetes is treated with antidiabetic drugs or subcutaneous insulin injection, these treatments do not provide the same degree of glycemic control as functional pancreatic $\beta$-cells and do not prevent the debilitating consequences of the disease. Treatments that replenish $\beta$-cell mass in diabetic patients could allow for the long-term restoration of normal glycemic control and thus represent a potentially curative therapy. Despite the fact that the primary causes for type I and type II diabetes mellitus (T2DM) differ, all diabetes will benefit from treatments that replenish their $\beta$-cell mass.

Regeneration of $\beta$-cells is usually extremely low except some special conditions like acute injury and pregnant in rodents and humans which imply the existence of $\beta$-cell regeneration mechanism under certain specific physiopathological conditions [2-7]. Researchers found mouse $\beta$-cells are the products of uniform self-renewal. It is lowered by a replication refractory period that prevents $\beta$-cells from immediately redividing [2]. $\beta$-cell progenitors can be activated in injured adult mouse pancreas. Differentiation of the adult progenitors is Ngn3 dependent and gives rise to all islet cell types, including glucose responsive $\beta$-cells. Multipotent progenitor cells exist in the pancreas of adult mice and can be activated autonomously to increase the functional $\beta$-cell mass by differentiation and proliferation [3]. Ectopic expression of Pax4 in the mouse pancreas converts progenitor cells into $\beta$-cells [4]. The evidence suggests $\beta$-cell regeneration is a process which can be induced.

Betatrophin, also called angiopoietin-like protein 8 (ANGPTL8) [8] lipasin [9-11], is a polypeptide and essentially secreted by liver or adipose tissue, and plays a major role on stimulating cell proliferation of islet cells and enhancing insulin producing in rodents [11-15]. However, the late studies in rodents found ANGPTL8 does not stimulate beta cell replication [16-18]. Human study showed that betatrophin concentrations were approximately $40 \%$ higher or doubled

${ }^{*}$ Corresponding author: Yong-Fu Xiao, MD, PhD, Cardiovascular and Metabolic Diseases Research, Crown Bioscience Inc., 6 Beijing West Road, Science \& Technology Park, Taicang Economic Development Area, Taicang, Jiangsu Province 215400, P.R. China, Tel: +86-512-5387-9826; Email: xiaoyongfu@crownbio.com

Received December 05, 2016; Accepted December 26, 2016; Published December 30, 2016

Citation: Yongqiang Liu, Xiaoli Wang, Bingdi Wang, Guofeng Sun, Francine Gregoire, et al. (2016) Dynamic Changes of Betatrophin and Its Potential Effect on $\beta$-cells in Spontaneously Developed or Streptozocin-induced Diabetes Monkeys. J Diabetes Metab 7: 719. doi: 10.4172/2155-6156.1000719

Copyright: (c) 2016 Yongqiang Liu, et al. This is an open-access article distributed under the terms of the Creative Commons Attribution License, which permits unrestricted use, distribution, and reproduction in any medium, provided the original author and source are credited. 
Citation: Yongqiang Liu, Xiaoli Wang, Bingdi Wang, Guofeng Sun, Francine Gregoire, et al. (2016) Dynamic Changes of Betatrophin and Its Potential Effect on $\beta$-cells in Spontaneously Developed or Streptozocin-induced Diabetes Monkeys. J Diabetes Metab 7: 719. doi: $10.4172 / 2155-6156.1000719$

Page 2 of 10

in patients with type I and type II diabetes compared with controls [19-23]. Betatrophin concentrations are dramatically increased during pregnancy and are significantly higher in gestational diabetes mellitus [24]. It has been known that diabetic pancreas pathophysiology differs in rodents from in humans greatly, but nonhuman primates (NHPs) are more close to humans [25-27]. Numerous studies have used spontaneously developed or streptozocin (STZ)-induced diabetic monkeys to investigate diabetes progression and therapy [28-32].

A spontaneously developed diabetic model gives us an insight of the naturally occurring process of diabetes in NHPs, but it may take years to show the phenotype and raise the difficulty to monitor the disease progress. While STZ-induced diabetes can be initiated in a short period of time and give us a dynamic process from non-diabetes to diabetes in a short duration. The change of blood betatrophin concentration and its correlation with other biological responses might provide important information for diabetes research and therapy. This study was to evaluate the dynamic changes of liver betatrophin transcription and its plasma level in spontaneously developed or STZ-induced diabetes monkeys. In addition, the correlations of betatrophin levels with islet sizes, insulin contents and blood glucose levels were examined.

\section{Methods}

Experiments were performed in cynomolgus $(n=65,20$ females with the age of $20.3 \pm 0.9$ years and 45 males with the age of $12.8 \pm 0.7$ years) and rhesus ( $\mathrm{n}=8,4$ females with their ages from 7 to 15 years and 4 males with their ages of 7 years) monkeys. These monkeys were individually housed and maintained in our animal facility in accordance with the guidelines approved by the Association for Assessment and Accreditation of Laboratory Animal Care (AAALAC). Animals had continuous access to water ad libitum and controlled access to food according to their body weights. Room temperature was maintained at $\sim 21^{\circ} \mathrm{C}$. The animals were maintained on a $12 \mathrm{hr}$ light/dark cycle with lights off from 7 PM to 7 AM. The monkeys were maintained with a complete, nutritionally balanced diet (Beijing Keao Xieli Feed Co., LTD, Beijing, China) and enriched with seasonal fruits and vegetables. The experimental protocol was approved by the Institutional Animal Care and Use Committee (IACUC) of Crown Bioscience, Inc.

\section{Streptozocin treatment and diabetes induction}

Seven normoglycemia rhesus monkeys were intravenously injected with STZ (Lot S0130, Sigma, USA) at $35 \mathrm{mg} / \mathrm{kg}(35 \mathrm{mg} / \mathrm{mL}$ dissolved in the PBS, phosphate buffer saline) once for diabetes induction and one animal was treated with the neutral PBS as control. The process of induction was similar to others reported in STZ monkey models $[29,30,32]$. The experimental animals were euthanized on day $7(n=5)$ and day $14(\mathrm{n}=3)$ after STZ or vehicle injection.

\section{Plasma and tissue collection}

After an animal was fasted overnight for approximately 16 hours, 2 to $3 \mathrm{~mL}$ whole blood was collected into K2-EDTA tube. The tubes were inverted for 10 times immediately then placed on ice. Plasma was separated by centrifugation at $3000 \mathrm{rpm}$ for $15 \mathrm{~min}$ at $4^{\circ} \mathrm{C}$. The plasma was stored at $-80^{\circ} \mathrm{C}$ until analysis.

For tissue collection, the animals were anesthetized with intramuscular injection of $15 \mathrm{mg} / \mathrm{kg}$ ketamine (Fujian Gutian Pharma, China) initially and then added $5 \mathrm{mg} / \mathrm{kg}$ as needed. The animal euthanasia was conducted with intravenous injection of sodium pentobarbital (Guangzhou Sile, China) at $100 \mathrm{mg} / \mathrm{kg}$. All the tissues or organs collected were processed in 10 times volume of $10 \%$ formalin or
RNAlater separately for later in vitro experiments. Tissues in formalin were incubated on a shaker for 24 hours and then washed 3 times with PBS. RNA later samples were incubated at $4^{\circ} \mathrm{C}$ overnight and then stored at $-80^{\circ} \mathrm{C}$ after pipetting the RNA later liquid into cryopreserved vials.

Serum glucose, insulin, Triglycerides (TG), high density lipoproteins (HDL), low density lipoproteins (LDL), alanine aminotransferase (ALT), aspartate aminotransferase (AST), creatinine, and Apolipoprotein B (APOB) were analyzed in the clinical lab (The First People's Hospital of Taicang, Taicang, Jiangsu Province, China). Betatrophin was tested with a monkey specific ELISA kit (Aviscera Bioscience, Santa Clara, CA, USA; EIAAB, Wuhan, China).

\section{Immunohistochemistry}

The paraffin embedded sections were deparaffinized/rehydrated in xylene followed by ethanol and PBS serial rehydration. Antigen retrieval was completed in $0.01 \mathrm{M}$ citrate buffer ( $\mathrm{pH}$ 6.2) for $30 \mathrm{~min}$ in boiling water. Sections were treated in $1 \%$ triton X-100 for 20 min and then blocked in PBS with 3\% goat serum and $0.03 \%$ Tween-20 for $30 \mathrm{~min}$. Incubation with the primary antibody (mouse anti-insulin monoclonal and rabbit anti-Ki67 polyclonal antibody) being diluted in $1 \%$ goat serum and $0.03 \%$ Tween-20 was performed at room temperature for 2 hours in a wet chamber. Three times washed with PBST (PBS with $0.03 \%$ Tween-20) were performed following incubation. Slides were incubated in PBS with Alexa Fluor 488 donkey anti-mouse IgG, Alexa Fluor 555 donkey anti-rabbit IgG, $0.5 \mu \mathrm{g} / \mathrm{mL}$ DAPI, $1 \%$ goat serum and $0.03 \%$ Tween-20 for $30 \mathrm{~min}$ in a wet chamber protected from light. After 3 times washed with PBST, slides were mounted with flumromount (Sigma, USA) for reading by microscope (Olympus BX51, Japan).

\section{Quantitative polymerase chain reaction}

Total RNA from the organs/tissues was extracted using RNAeasy plus mini kit (Qiagen), and genomic DNA was digested using RNase free DNase. For real-time PCR analysis, cDNA was synthesized using Superscript III First Strand cDNA synthesis kit (Invitrogen). Amplification of Betatrophin and the internal control of GAPDH were conducted on Stratagene Mx3005p (Agilent Technologies) by using the SYBR-green reaction system.

\section{Intravenous glucose tolerance test (ivGTT)}

To evaluate $\beta$-cell function ivGTT was performed in the experimental monkeys according to the method reported previously $[33,34]$. The animals were fasted for overnight $16 \mathrm{hrs}$ and then anesthetized with an initial dose of ketamine at $10 \mathrm{mg} / \mathrm{kg}$ (i.m.) plus one additional dose of $5 \mathrm{mg} / \mathrm{kg}$ during the procedure when needed. The monkey was heated with a circulating water pad $\left(37^{\circ} \mathrm{C}\right)$ to prevent body temperature drop. The cephalic and/or saphenous veins were cannulated separately for glucose infusion and blood collection. Glucose $(0.25 \mathrm{~g} / \mathrm{kg}=0.5 \mathrm{~mL} / \mathrm{kg}$ of $50 \%$ dextrose) was intravenously infused during $30 \mathrm{sec}$ and the system was then flushed with $5 \mathrm{~mL}$ heparinized saline to push in the residual glucose. Blood was collected from a different vein into heparinized tubes pre-chilled on ice immediately before and at $3,5,7,10,15,20$, 30 and $60 \mathrm{~min}$ after glucose infusion. Plasma was then separated and stored at $-80^{\circ} \mathrm{C}$ for subsequent assays lately.

\section{Data Analysis}

Data were expressed as mean \pm standard error of the mean. Statistical significance for multiple observation parameters in the same group was determined by One-way Analysis of Variance. If statistical significance of differences was detected, then Tukey's Multiple 
Citation: Yongqiang Liu, Xiaoli Wang, Bingdi Wang, Guofeng Sun, Francine Gregoire, et al. (2016) Dynamic Changes of Betatrophin and Its Potential Effect on $\beta$-cells in Spontaneously Developed or Streptozocin-induced Diabetes Monkeys. J Diabetes Metab 7: 719. doi: $10.4172 / 2155-6156.1000719$

Page 3 of 10

Comparison Test (GraphPad Software, Inc., La Jolla, CA, USA) was also conducted to determine the significance. The comparison between diabetic and normoglycemic groups was tested by the un-paired t-test. Statistical significance was considered if $\mathrm{p}$ value was $<0.05$.

\section{Results}

\section{Correlation between blood betatrophin and other parameters in spontaneously developed diabetic monkeys}

To investigate if the gender of our housed monkeys affected blood betatrophin level and other parameters, blood samples were collected from overnight fasted adult diabetes cynomolgus monkeys under conscious condition. Compared with the male animals, the plasma levels of glucose, $\mathrm{HbAlc}$, TC and TG were significantly higher in the housed female monkeys (Figure 1). The body weights were significantly

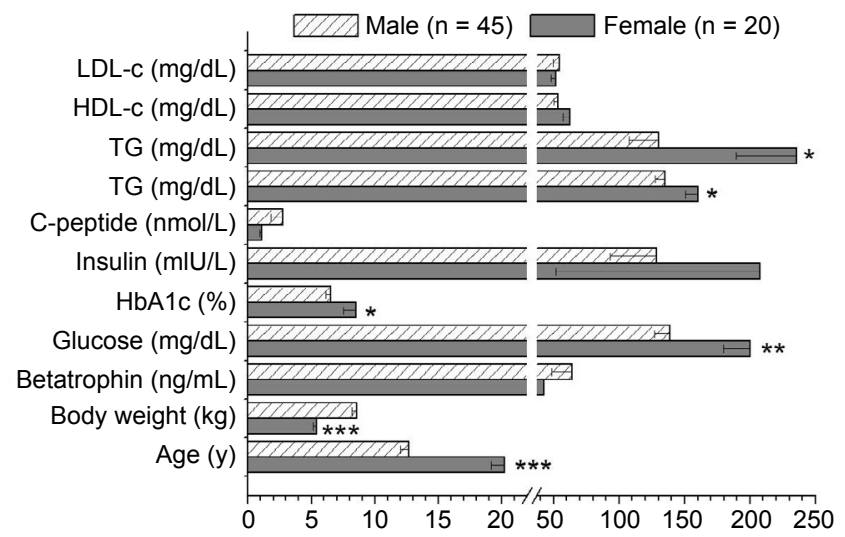

Figure 1: Comparison of use of antibiotics and infections between the groups.
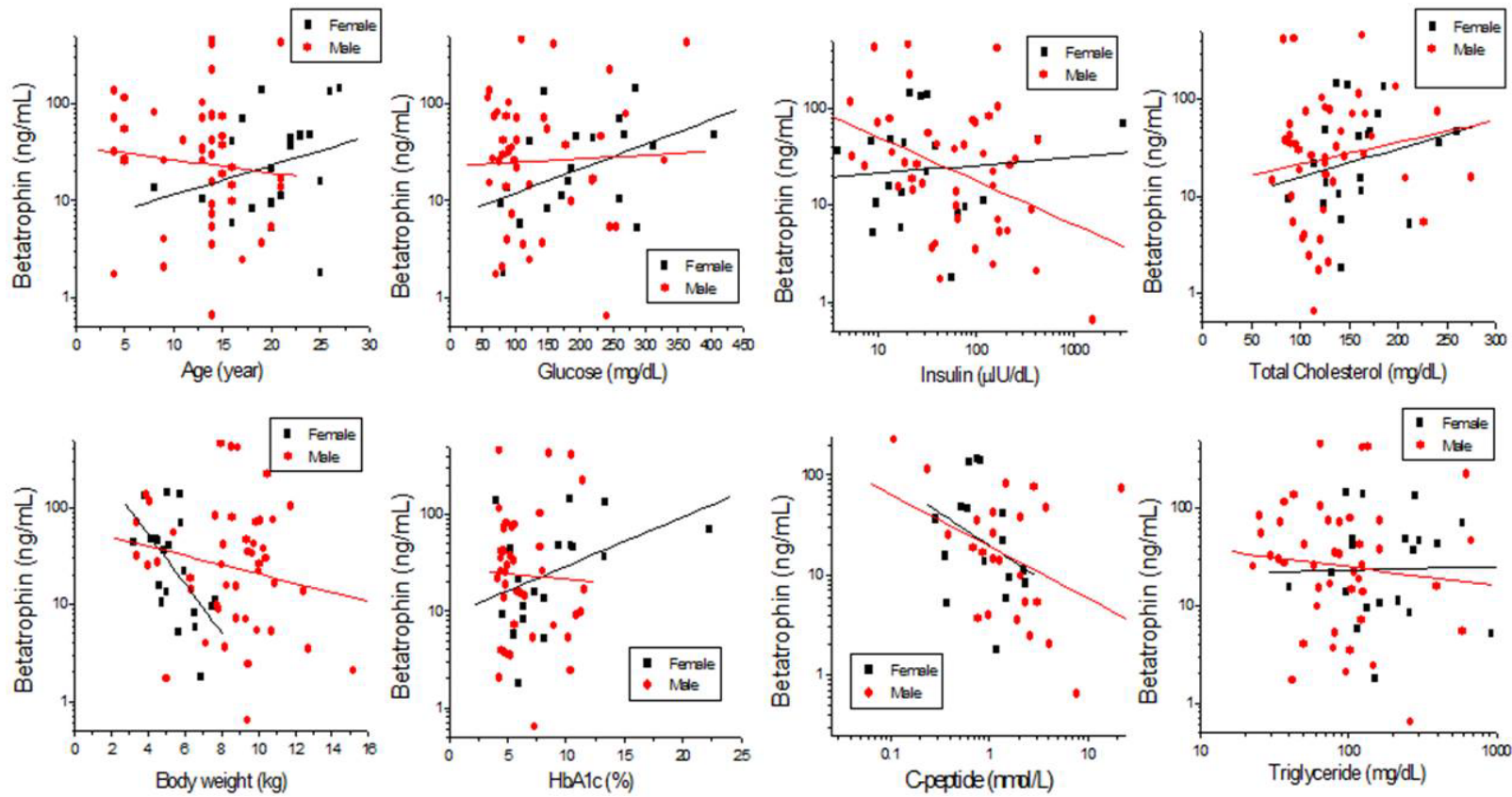

lower in the females than in the males, but the plasma levels of betatrophin, insulin, C-peptide, HDLc and LDLc were not significantly different between the males and females (Figure 1). It is interesting that the plasma betatrophin levels correlated positively with the plasma glucose levels and negatively with the body weights in the female monkeys $(\mathrm{p}<0.05, \mathrm{n}=20$, Figure $2 \mathrm{~B}$ and $2 \mathrm{E})$ and correlated negatively with the plasma insulin and C-peptide levels in the males $(\mathrm{p}<0.05$, $\mathrm{n}=45$, Figure $2 \mathrm{C}$ and $2 \mathrm{G}$ ). However, other parameters measured, such as age, plasma TC, HbAlc and TG levels, were not significantly correlated with plasma betatrophin levels in both males and females ( $\mathrm{p}>0.05$, Figure 2A, 2D, 2F, 2H)

To understand if insulin treatment affected betatrophin production, plasma betatrophin and other metabolic parameters were measured and compared between insulin-dependent and insulinindependent diabetes cynomolgus monkeys. The insulin-dependent monkeys were obviously much older than non-insulin-dependent ones ( $\mathrm{p}<0.01$, Figure 3 ). Compared with the non-insulin dependent animals, the insulin-dependent monkeys showed significantly higher levels of plasma betatrophin, glucose, $\mathrm{HbA1c}$, insulin, TC and TG (Figure 3). The parameters of body weight, C-peptide, HDLc and LDLc were not significantly different among the animals with or without insulin treatment (Figure 3).

\section{Betatrophin expression in various tissues from diabetic monkeys}

To determine the expression levels of betatrophin in different tissues, 6 cynomolgus monkeys with various blood glucose levels were sacrificed (Table 1) and multiple organs and tissues were collected. Figure 4A shows betatrophin mRNA expression levels in different NHP tissues. Clearly, betatrophin mRNA dominantly expressed in the liver of the monkeys. In the adult monkeys with blood glucose $<90 \mathrm{mg} /$ $\mathrm{dL}$, the levels of betatrophin mRNA expressed in the liver correlated

Figure 2: Blood betatrophin levels correlated significantly with the body weights $(p<0.01)$ and blood glucose levels $(p<0.05)$ in the female cynomolgus monkeys $(n=20)$ and correlated significantly with insulin $(p<0.01)$ and C-peptide $(p<0.05)$ levels in the male monkeys $(n=45)$. However, all other measured blood parameters showed in the figure had no significant correlations with blood betatrophin levels $(p>0.05)$. 
Citation: Yongqiang Liu, Xiaoli Wang, Bingdi Wang, Guofeng Sun, Francine Gregoire, et al. (2016) Dynamic Changes of Betatrophin and Its Potential Effect on $\beta$-cells in Spontaneously Developed or Streptozocin-induced Diabetes Monkeys. J Diabetes Metab 7: 719. doi: $10.4172 / 2155-6156.1000719$

Page 4 of 10

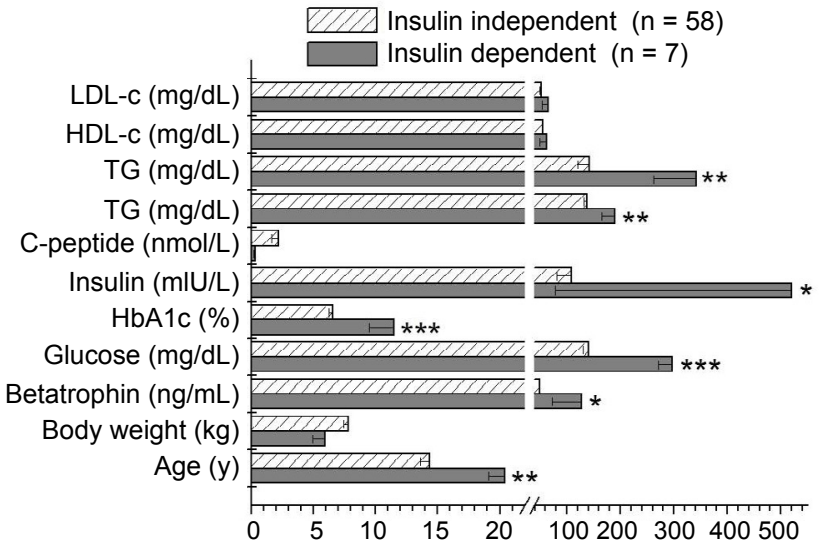

Figure 3: Comparison of the general metabolic parameters between insulin independent and dependent cynomolgus monkeys. $p>0.05^{\star} ; \quad p<0.01^{* *}$; $\mathrm{p}<0.05^{\star * *}$; insulin independent versus insulin dependent.

\begin{tabular}{|c|c|c|c|c|}
\hline Animal ID & Age (year) & $\begin{array}{c}\text { Body weight } \\
\mathbf{( k g )}\end{array}$ & $\begin{array}{c}\text { Fasting } \\
\text { glucose (mg/ } \\
\mathbf{d L})\end{array}$ & $\begin{array}{c}\text { Fasting } \\
\text { insulin } \\
\text { (mIU/L) }\end{array}$ \\
\hline V03 & 12 & 4.2 & 77 & 15 \\
\hline J01 & 19 & 8.2 & 57 & 46 \\
\hline D05 & 22 & 14.1 & 87 & 122 \\
\hline G01 & 15 & 8.6 & 250 & 301 \\
\hline M04 & 22 & 6.1 & 67 & 127 \\
\hline V04 & 20 & 3.6 & 212 & 3 \\
\hline
\end{tabular}

Table 1: Characteristics of the cynomolgus monkeys enrolled in the experiment.

well with the islet size and insulin content (Figures $4 \mathrm{~B}$ and 5). However, compared with the normoglycemia animals, the diabetic monkeys expressed markedly higher betatrophin mRNA in their livers. Two different correlations were observed between liver betatrophin mRNA levels and islet sizes in the diabetic monkeys. The betatrophin mRNA level in the liver correlated well with the islet size in the animal G01 who had hyperglycemia (>200 mg/dL) and high blood insulin (Figures $4 \mathrm{~B}$ and $5 \mathrm{C}$ ). However, another hyperglycemia animal V04, who was older and suffered from diabetes for a longtime, with extremely high betatrophin mRNA expression and very low blood insulin did not show the increase in islet size (Table 1, Figures 4B and 5D).

\section{Dynamic changes of betatrophin in STZ-induced diabetic monkeys}

The above data from the spontaneously developed diabetes cynomolgus monkeys suggest that betatrophin had certain correlations with diabetes development and $\beta$-cell function. However, the progress of naturally developed diabetes in NHPs takes a longtime and is hardly to predict or separate the stages. The streptozocin-induced diabetes model in various monkey colonies has been characterized and used in many metabolic studies $[29,32,35]$. Therefore, in order to investigate the dynamic changes of betatrophin and $\beta$-cells, a STZ-induced diabetes model was conducted in rhesus monkeys (Table 2). Seven of eight normoglycemic rhesus monkeys were administered with $35 \mathrm{mg} /$ $\mathrm{kg}$ STZ, because one study showed that monkeys treated with both 100 and $68 \mathrm{mg} / \mathrm{kg}$ of STZ exhibited continuous hyperglycemia, which coincided with a nearly complete loss of islet $\beta$-cells [28]. In order to preserve some $\beta$-cells, a relatively low dose of STZ was thus applied in our study. The blood betatrophin and glucose levels were markedly increased after STZ treatment. Blood insulin initially increased on day 1 after STZ and then decreased (Figure 6A). Hyperglycemia and hypo-insulin were successfully induced after STZ treatment except one monkey was died of high plasma glucose $(594 \mathrm{mg} / \mathrm{dL})$ and ketone $(9 \mathrm{mM} / \mathrm{L}) 1$ day after STZ administration. Both plasma glucose and betatrophin increased dramatically with a decrease in insulin (Figure 6A). Plasma betatrophin markedly increased in one to two days with glucose increase and insulin decrease after STZ injection. Intravenous GTT in the STZ-treated monkey after overnight fasting showed a typical diabetic response with almost no insulin secretion during ivGTT (Figure 6B)

Immunohistochemical staining of islets showed no obvious $\beta$-cell proliferation in the vehicle-treated monkey (Figure 7A). However, the islets in two STZ-treated NHPs with partial recovery of blood glucose, from $120 \mathrm{mg} / \mathrm{dL}$ on day 1 after STZ injection to $80 \mathrm{mg} / \mathrm{dL}$ on day 7 and $65 \mathrm{mg} / \mathrm{dL}$ on day 14 after STZ dosing (Figure 7B), clearly showed $\beta$-cell regeneration. In another two STZ-treated animals with higher blood glucose, $>300 \mathrm{mg} / \mathrm{dL}$, even more $\beta$-cell proliferation was observed in their islets (Figure 7C), but no recovery of blood glucose on day 7 . The islets in the remaining two STZ-treated animals with blood glucose

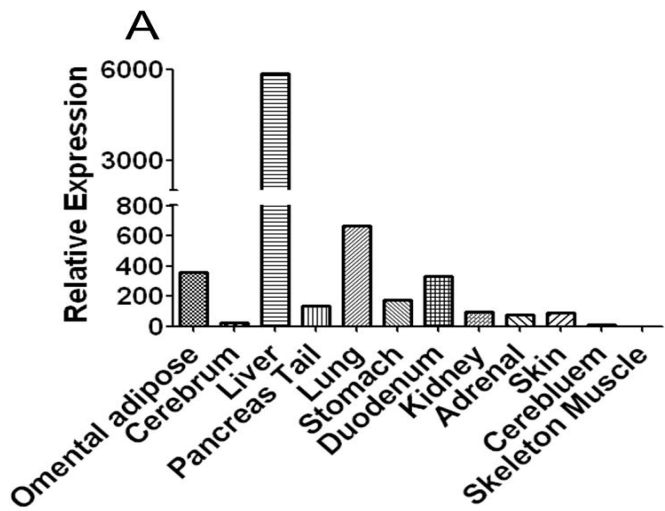

B

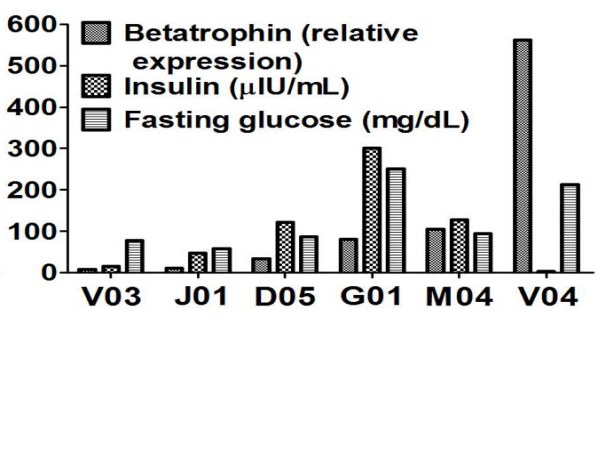

Figure 4: Betatrophin mRNA expression levels in different tissues of cynomolgus monkey are shown (A). Total RNA was extracted from the liver and other tissues of one monkey. The cDNA was synthesized by superscript III First Strand cDNA synthesis kit. Real-time PCR of betatrophin and the internal control of GAPDH was conducted on Stratagene Mx3005p (Agilent Technologies) using the SYBR-green reaction system. Relative quantity of betatrophin mRNA was calculated by $\triangle \Delta C T$ method. B, Correlation of liver betatrophin mRNA levels with blood glucose and insulin concentration. Serum insulin and glucose levels were tested. Betatrophin mRNA expression showed high correlation with blood insulin and glucose levels except V04. V03, J01, D05, G01, M04 and V04 were the actual animal IDs used during the study.. 
Citation: Yongqiang Liu, Xiaoli Wang, Bingdi Wang, Guofeng Sun, Francine Gregoire, et al. (2016) Dynamic Changes of Betatrophin and Its Potential Effect on $\beta$-cells in Spontaneously Developed or Streptozocin-induced Diabetes Monkeys. J Diabetes Metab 7: 719. doi: $10.4172 / 2155-6156.1000719$
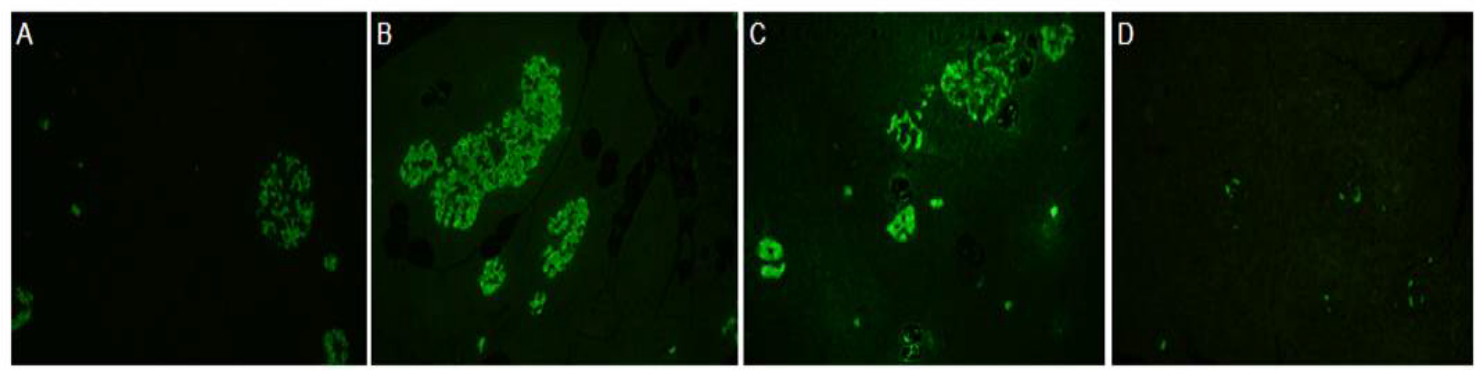

Figure 5: Correlation between liver betatrophin mRNA levels and islets quantities and sizes in the pancreas (insulin immunohistochemistry, 10X). Betatrophin relative expression in liver was analyzed by real-time PCR. Paraffin section was stained by mouse anti-insulin antibody. Normal betatrophin level with some small islets in normal monkey V03 (A). High betatrophin level with increased islets number in prediabetic monkey M04 (B). High betatrophin level with expand islets in diabetic monkey G01 (C). High level betatrophin with rare beta cells in pancreas in severe diabetic monkey V04 (D).

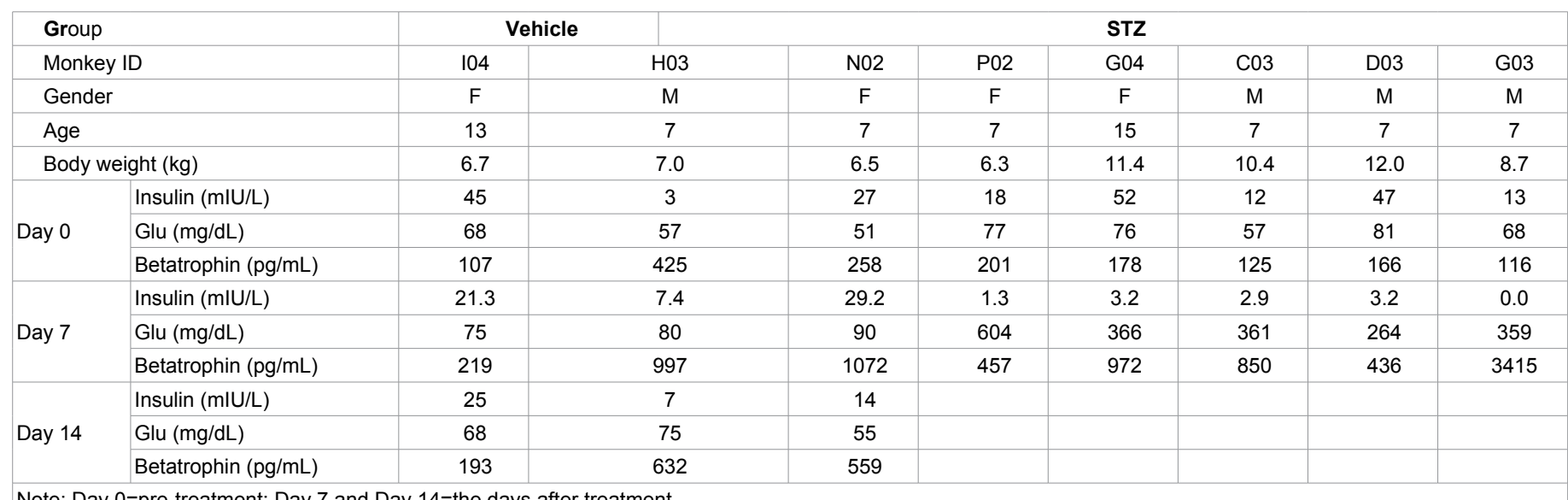

Note: Day $0=$ pre-treatment; Day 7 and Day $14=$ the days after treatment.

Table 2: General information of the animals enrolled for STZ treatment.
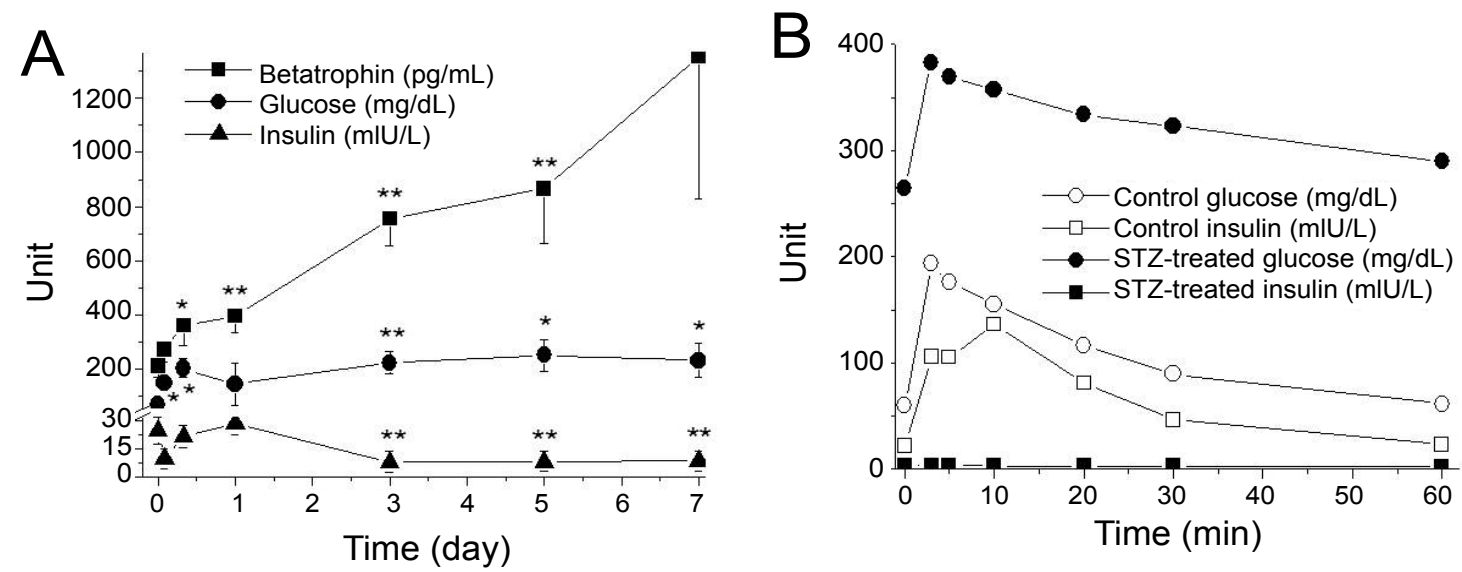

Figure 6: Effects of STZ on blood betatrophin, glucose and insulin in NHPs. (A) Elevation of blood glucose and betatrophin during diabetic induction after STZ injection on day 0 . (B) Changes of blood glucose and insulin during ivGTT conducted before (Control) and on day 7 after STZ injection (STZ-treated) in one NHP. p<0.05*; $<0.01^{\star *} ;$ versus day 0 for glucose and betatrophin; versus day 1 for insulin.

$>300 \mathrm{mg} / \mathrm{dL}$, whose $\beta$-cells were severely destroyed, showed little $\beta$-cell proliferation (Figure 7D). In addition, betatrophin mRNA relative expression in the liver was $50 \%$ higher in STZ-treated group than in the vehicle one (Figure 8A). The $\beta$-cell proliferation was approximately
20 times higher in the STZ-treated group than in the vehicle animal (Figure $8 \mathrm{~B}$ ). To examine the dynamic changes of blood glucose and betatrophin, the experimental duration was extended to 14 days in 3 animals with repeated ivGTTs. The vehicle animal had no obvious 
Citation: Yongqiang Liu, Xiaoli Wang, Bingdi Wang, Guofeng Sun, Francine Gregoire, et al. (2016) Dynamic Changes of Betatrophin and Its Potential Effect on $\beta$-cells in Spontaneously Developed or Streptozocin-induced Diabetes Monkeys. J Diabetes Metab 7: 719. doi: $10.4172 / 2155-6156.1000719$
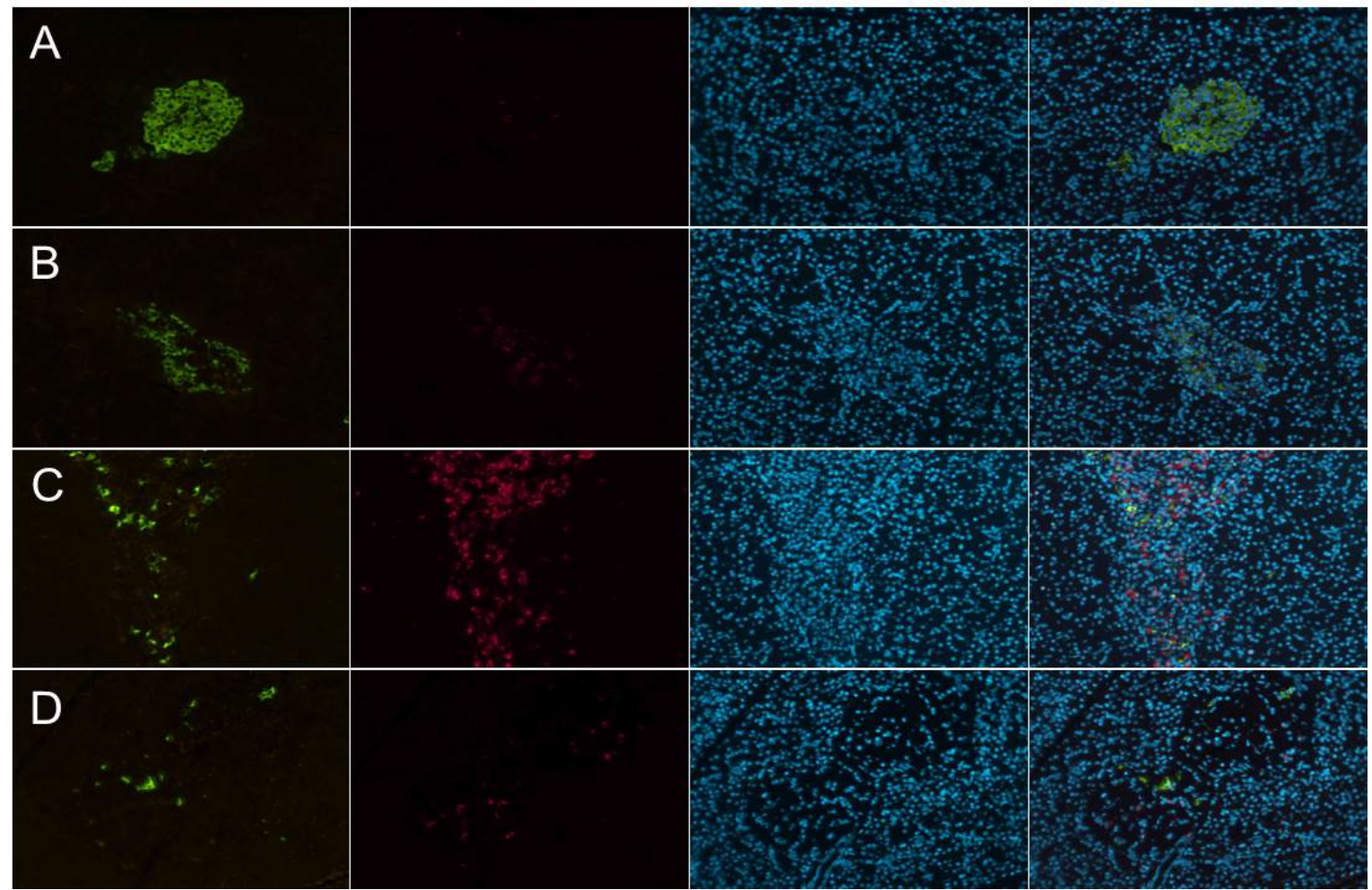

Figure 7: Immunohistochemical staining of paraffin-sectioned pancreatic islets (20X) against insulin, Ki67 and DAPI. (A) Islets from the vehicle treated animal showed no obvious $\beta$-cell proliferation. (B) Moderate $\beta$-cell proliferation was shown in islets of two STZ-induced hyperglycemic monkeys with recovery of blood glucose, from $120 \mathrm{mg} / \mathrm{dL}$ on day 1 to $80 \mathrm{mg} / \mathrm{dL}$ on day 7 and then to $65 \mathrm{mg} / \mathrm{dL}$ on day 14, respectively, after STZ administration. (C) Obvious $\beta$-cell proliferation in islets was observed in other 2 STZtreated animals with hyperglycemia constantly above $300 \mathrm{mg} / \mathrm{dL}$ on day 7 after STZ dosing. (D) Islets from the rest of 2 STZ-treated animals with constant $>300 \mathrm{mg} / \mathrm{dL}$ blood glucose and severe destruction of islets showed rare $\beta$-cell proliferation on day 7 after STZ injection.

A

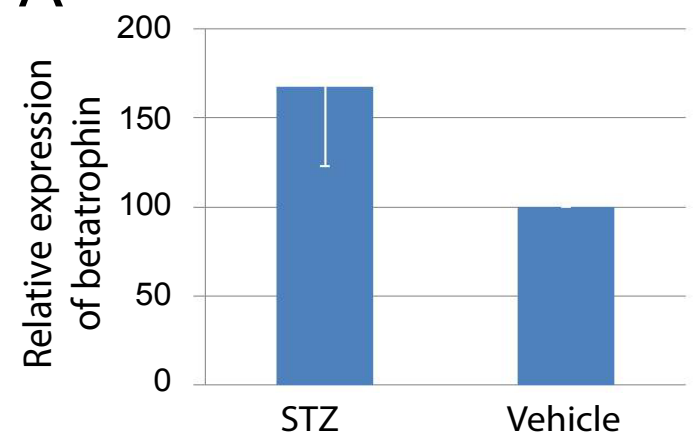

$\mathrm{B}$

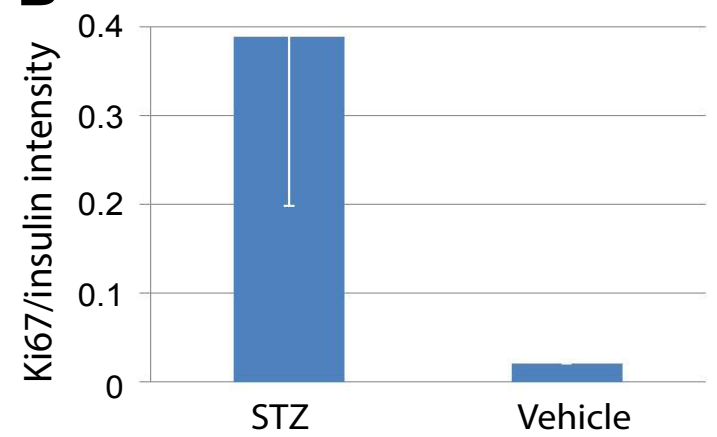

Figure 8: Betatrophin relative expression in liver and $\beta$-cell proliferation in pancreas after STZ treatment. (A) Betatrophin mRNA expression in liver in vehicle ( $n=1)$ and STZ-treated animals $(n=7)$. Total RNA was extracted from liver tissue and then reversely transcribed into single strand cDNA. Betatrophin mRNA relative expression levels (GAPDH as internal control) were conducted by real-time PCR. (B) Beta-cell proliferation rate comparison among the vehicle ( $n=1$ ) and STZ-treated animals ( $n=7$ ). IHC of the antibody and conjugated dye against insulin or Ki67 was performed in the pancreas paraffin sections and staining intensity was quantified with the software Image $\mathrm{J}$ (National Institutes of Health, USA).

change on ivGTT during the study (Figure 9A), but the STZ-treated animals recovered toward the pre-treated level on day 14 (Figure 9B). The blood glucose decreased consecutively after the initial increase in 3 days after STZ treatment (Figure 9C) and betatrophin decreased at the end of the 2nd week after STZ injection (Figure 9D). Our data may explain, at least partially, why circulating betatrophin level is elevated in patients with type 2 diabetes.

\section{Discussion}

The main finding of this study is that liver expressed abundant mRNA of betatrophin in NHPs. The expression levels correlated well with blood betatrophin contents and islet sizes in most naturally developed diabetic cynomolgus monkeys. In addition, blood betatrophin levels showed dynamic changes during the process of STZ-induced diabetes 
Citation: Yongqiang Liu, Xiaoli Wang, Bingdi Wang, Guofeng Sun, Francine Gregoire, et al. (2016) Dynamic Changes of Betatrophin and Its Potential Effect on $\beta$-cells in Spontaneously Developed or Streptozocin-induced Diabetes Monkeys. J Diabetes Metab 7: 719. doi: $10.4172 / 2155-6156.1000719$

Page 7 of 10
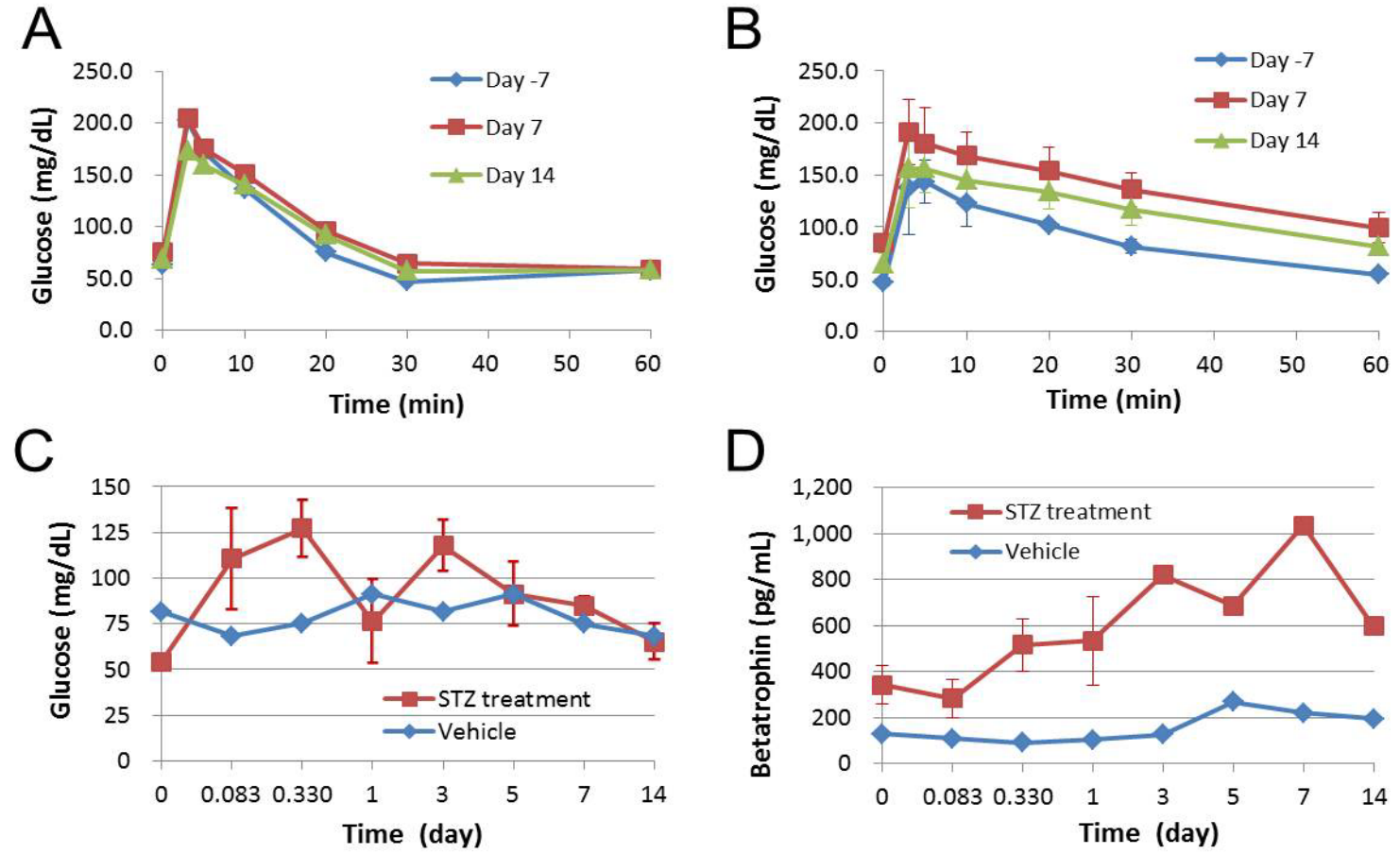

Figure 9: Changes of blood betatrophin and glucose in STZ-treated animals. Three times of ivGTT were conducted under anesthesia on day $-7,7$ and 14 in STZ ( $\mathrm{n}=2$ ) or vehicle $(n=1)$ treated animals with overnight $(\sim 16 \mathrm{hrs})$ fast. The ivGTT curves overlapped well in the vehicle control (A). However, the curve of ivGTT in two STZ treated animals shifted up markedly on day 7 after STZ-treatment and returned toward to the baseline with slower glucose clearance rate (compared with day -7) on day 14 after STZ administration (B). The time course of blood glucose showed no change in vehicle animal $(n=1)$, but in STZ-treated animals ( $n=2)$ showed the initial increase within day 1 and 2nd increase on day 3 and then descended continuously toward the pretreatment level (C). Compared with the vehicle animal, blood betatrophin in the STZ-treated animals increased gradually from day 1 until its peak on day 7 after STZ administration and then declined toward the pre-treatment level (D).

in rhesus monkeys. Beta-cell proliferation or regeneration was observed in diabetic animals with high blood betatrophin. However, such regeneration seems requiring a base number of pancreatic islets or $\beta$-cells, which means that the betatrophin effect on $\beta$-cell regeneration was greatly diminished in animals with little functional islets and $\beta$-cells. The main cause in most diabetes patients is insulin resistance and eventually $\beta$-cell failure or depletion. An effective approach to cure diabetes is thus to recover pancreatic function via replenishing the lost or dysfunctional $\beta$-cells.

Betatrophin, a polypeptide, primarily produced in the liver showed the enhancement effect on $\beta$-cell regeneration/proliferation and insulin secretion in in early rodent study [12,36], but such effect was not disapproved in late studies [16-18]. The islets between rodents and primates exists obvious differences in the structure and signaling pathway. Insulin-immunoreactive, glucagonimmunoreactive and somatostatin-immunoreactive cells were found all randomly distributed in human and monkey islets. In contrast, insulin-containing cells were located in the core, and glucagon- and somatostatin-containing cells in the mantle of mouse islets $[25,26]$. Such differences made our current study highly valuable as betatrophin also dominantly expressed and produced in the liver and increased dramatically in diabetes NHPs. In addition, betatrophin potentially enhanced $\beta$-cell regeneration in diabetes monkeys (Figures 4 and $5)$. It is interesting that blood betatrophin level was similar in the diabetic males to females (Figure 1), even though the female monkeys were older with significantly higher levels of blood glucose, TG and TC. However, compared with the insulin-independent monkeys, the blood betatrophin level was significantly higher in the group of insulin-dependent monkeys (Figure 3). The group with insulin-dependent diabetes had significantly older age and higher levels of blood glucose, HbA1c, TG and TC, which might be the causes leading to higher blood betatrophin [37]. This phenomenon is similar to the clinical finding that elevated betatrophin levels were measured in the patients with type 2 diabetes [19,20,23,38]. Meta-analysis showed that circulating betatrophin level of T2DM patients is higher than that of nondiabetic adults in the non-obese population, but not in the obese population [39]. Betatrophin positively correlated with age in the controls and with HbAlc in type 2 diabetes patients [21,22]. In addition, plasma betatrophin concentrations in diabetes patients were positively correlated with duration of Type 2 diabetes and negatively correlated with increments of $\mathrm{C}$-peptide concentration and creatinine clearance [40]. However, one recent study showed betatrophin and irisin were not associated with $\beta$-cell function in previously diagnosed T2DM patients [41].

In the current study, the relative expression level of betatrophin in the liver was highly correlated with the plasma glucose level and rate of new cell regeneration in NHPs. In adult monkeys with blood glucose $<90 \mathrm{mg} / \mathrm{dL}$, the liver mRNA levels of betatrophin correlated well with the islet sizes and insulin contents. However, the diabetic animals expressed markedly higher betatrophin mRNA in their livers showed two different correlation patterns between liver betatrophin mRNA levels and islet sizes. In hyperglycemic NHPs, the betatrophin mRNA levels in the liver correlated well with the islet sizes in the animals with high blood insulin, but not correlated well in those with very low blood insulin (Figures 4 and 5). Immunohistological analysis of the pancreas showed that the islets in the diabetic animals with high blood insulin 
Citation: Yongqiang Liu, Xiaoli Wang, Bingdi Wang, Guofeng Sun, Francine Gregoire, et al. (2016) Dynamic Changes of Betatrophin and Its Potential Effect on $\beta$-cells in Spontaneously Developed or Streptozocin-induced Diabetes Monkeys. J Diabetes Metab 7: 719. doi: $10.4172 / 2155-6156.1000719$

were larger and contained more insulin, whereas the islets in those diabetic NHPs with low blood insulin showed much less $\beta$-cells and less insulin. High betatrophin seemed ineffective in animals at latestage diabetes with very low insulin, probably due to dysfunction or depletion of $\beta$-cells. Plasma betatrophin levels correlated well with plasma glucose levels in the female monkeys and correlated well with insulin levels in the male monkeys (Figure 2). Such differences could be age-related as the males were significantly younger than the females (Figure 1). Therefore, the diabetic stage in the females could be more advanced. In rodents, an increase in hepatic betatrophin gene expression stimulated mouse $\beta$-cell replication [42]. However, Gusarova et al. reported that $\beta$-cell proliferation was not affected by the lack of ANGPTL8 in response to diet induced insulin resistance or the S961 insulin receptor antagonist treatment in ANGPTL8 knockout mice [18]. The results from two recent studies also demonstrate that ANGPTL8 does not stimulate significant $\beta$-cell proliferation $[16,17]$. In addition, human $\beta$-cells were completely unresponsive to betatrophin stimulation. These results questioned whether betatrophin can be developed as a therapeutic approach for treating human diabetes [42]. Betatrophin levels were also affected by other parameters, such as triglycerides $[38,43]$. In this study, TG and TC were also significantly higher in naturally developed diabetes NHPs, which might also be the factors affecting betatrophin levels (Figures 1 and 3) [44].

Immunohistological analysis of the pancreas showed that the islets in the diabetic animals with high blood insulin were larger and contained more insulin, whereas the islets in those diabetic NHPs with low blood insulin were smaller and contained less insulin. Our results indicate that betatrophin is expressed in NHP liver and might play an important role in $\beta$-cell regeneration at the early stage of diabetes in diabetic monkeys with high blood insulin, because its levels correlated well with islet sizes and insulin contents. However, high betatrophin could be ineffective in animals at late-stage diabetes with very low insulin, probably due to depletion of $\beta$-cells. Elevated triglycerides accompanied with increased betatrophin may also be a clue to explore the mechanism of betatrophin triggered $\beta$-cells replenishment.

STZ-induced hyperglycemia in various species have been used for biomedical research [45-47]. If the STZ dose was $60 \mathrm{mg} / \mathrm{kg}$ or higher, it easily induces marked hyperglycemia $[30,32,35]$. In this study single injection of $35 \mathrm{mg} / \mathrm{kg} \mathrm{STZ}$ in adult normoglycemia NHPs successfully induced hyperglycemia/hypoinsulinemia (Table 2) to mimic acutely progressed diabetes and then the dynamic changes of blood betatrophin were examined. In STZ-induced rhesus monkeys with normal blood glucose less than $80 \mathrm{mg} / \mathrm{dL}$, blood betatrophin and glucose levels increased dramatically after STZ-induced $\beta$-cell destruction. In STZ-treated NHPs except one animal died on the 2nd day after STZ treatment, blood betatrophin increased dramatically and proliferation of pancreas cells show high correlation with the increased plasma betatrophin especially in 2 animals with partially recovered blood glucose level, from $120 \mathrm{mg} / \mathrm{dL}$ to $80 \mathrm{mg} / \mathrm{dL} 7$ days after STZ treatment. In another 2 STZ-treated animals with higher blood glucose, $>250 \mathrm{mg} /$ $\mathrm{dL}$, more cell proliferation was observed in none $\beta$-cell area in the islets even though obvious increased $\beta$-cell proliferation was found. The rest 2 STZ treated animals whose $\beta$-cells were severely destroyed showed little $\beta$-cell proliferation. In addition, rare proliferated $\beta$-cells or $\alpha$-cells were observed in the vehicle treated animal (Figure 7). While, elevated triglycerides were also found in the STZ-treated animals accompanied with increased betatrophin.

Blood betatrophin concentrations changed dynamically and highly correlated with the blood glucose levels during the STZ induction process. Betatrophin and glucose levels increased initially and then subsided lately after STZ administration, which indicates there might be some feedback stimulation and inhibition. The relative expression of liver betatrophin increased by over 50\% in STZ treated animals compared with vehicle animal (Figure 8A). The level of $\beta$-cell regeneration was likely different at various diabetes stages and damaged levels of the pancreas. Beta cell proliferation rate is not high in the pancreas with severely destroyed islets. The data demonstrate that blood betatrophin rose parallelly with glucose elevation during STZ induction of diabetes in NHPs. Such increase in blood betatrophin led to $\beta$-cell regeneration in some animals, 5 out of 7 , but not in those NHPs with severely destroyed islets, 2 out of 7. In 2 STZ-induced animals blood glucose went back toward their pre-STZ levels 7 to 14 days after STZ dosing. Their ivGTT tests on day 14 also had their glucose clearances similar to those before STZ treatment (Figure 9B).

Beta-cell replication is extremely low under normal condition and is elevated by 4 -fold during gestation, 2 - to 4.5 -fold with high glucose infusion, and 4 -fold in a $\beta$-cell ablation model $[7,48,49]$. Compared with the control, $\beta$-cell regeneration increased multiple times in most STZtreated NHPs, which suggests the potential effect of betatrophin on $\beta$-cell replenishment (Figures 7 and 8 ). However, either STZ-induced or spontaneously developed diabetes animals with mostly destroyed islets had little $\beta$-cell regeneration. These results suggest that certain number of $\beta$-cells are needed for betatrophin to trigger off obvious regeneration or more $\beta$-cell death overrides the regenerated ones. Therefore, the mass of $\beta$ cells represents the balance between $\beta$-cell growth (differentiation and replication) and death (apoptosis). Even with high concentration of betatrophin, this balance may not be reached if the number of $\beta$-cells is too low, which possibly explain why some NHPs at late stage diabetes have high betatrophin, but show little $\beta$-cell regeneration (Figures 5, 7 and 8 ). In adults, $\beta$-cell regeneration can result from existing $\beta$-cells or precursor cells. Also, $\beta$-cell regeneration can be achieved from exocrine cells and proliferation of ducts and their subsequent differentiation into new pancreatic lobes [50-52]. In our study, most of the Ki67 staining was located in islets but not ductile which indicates the new generated $\beta$-cells were from replication of existing $\beta$-cells or precursor cells [53]. The mechanism how betatrophin induces $\beta$-cell regeneration is still unclear. Some studies showed that betatrophin involved in irisin stimulated $\beta$-cell regeneration at the downstream of the signal pathway $[54,55]$. In addition, pregnancy in mice stimulated proliferation of maternal pancreatic islet $\beta$-cells accompanied by reduced islet levels of menin and its targets, and prolactin repressed islet menin levels and stimulated beta-cell proliferation [7]. It is unclear if betatrophininduced $\beta$-cell regeneration in NHPs also involved menin or prolactin.

Our study demonstrates the dynamic changes of betatrophin and its potential effects on $\beta$-cell regeneration in both spontaneously developed and STZ-induced diabetic monkeys. However, there are several limitations on the interpretation of the results. Firstly, blood betatrophin were measured in a large group of spontaneously diabetes monkeys (Figures 1-3, $\mathrm{n}=65$ ), but the immunohistological data were obtained from very limited number of animals (Figures 4 and 5, $\mathrm{n}=6$ ). Therefore, some distortion potentially occurred when various correlations were analyzed. Secondly, the animal number and duration of STZ experiment were relatively small, especially for control $(n=1)$, and short (only 1 week for baseline and 2 weeks after STZ treatment) with limited sampling points, including tissue collection. Thirdly, there is a lack of mechanistic experiments. Therefore, the data were relatively incomplete and hard to make statistical analysis and conclusion. More studies are required to delineate why betatrophin likely loses its effects on $\beta$-cells at the late stage of diabetes in NHPs, which may provide 
Citation: Yongqiang Liu, Xiaoli Wang, Bingdi Wang, Guofeng Sun, Francine Gregoire, et al. (2016) Dynamic Changes of Betatrophin and Its Potential Effect on $\beta$-cells in Spontaneously Developed or Streptozocin-induced Diabetes Monkeys. J Diabetes Metab 7: 719. doi: $10.4172 / 2155-6156.1000719$

vital information for understanding the role of this polypeptide during disease development.

In conclusion, spontaneously developed or STZ-induced diabetic NHPs had high blood betatrophin which might enhance $\beta$-cell proliferation in most cases. Betatrophin effect on $\beta$-cell proliferation could be via stimulating the remained $\beta$-cells to replicate. Therefore, a minimal base level of pancreatic $\beta$-cells or islets might be required for betatrophin effect on $\beta$-cell replication. The increased circulating betatrophin could contribute to the lately occurred recovery from STZinduced hyperglycemia toward the pre-STZ glucose level. Further study is required to find the solid correlation between betatrophin and $\beta$-cell replication in NHPs.

\section{Declaration}

Ethics approval and consent to participate: This is not a human study. Ethics approval and consent are thus not applicable. The study protocol and experimental procedures for suing the animals were approved by the IACUC of Crown Bioscience Inc with the members outside of the company.

Consent for publication: All the authors have read and approved the manuscript for submission and their consents are available if requested.

Availability of data and material: All the materials and relevant raw data supporting our findings can be found in Tables and Figures in the manuscript and are freely available to readers or scientists wishing to use them for non-commercial purposes.

Competing interests: All of the authors are employee of Crown Bioscience, Inc., except J Wang who is employee of Taicang Affiliated Hospital of Soochow University. The authors declare no conflict of interest in this study.

Funding: This study was supported by the internal research fund of Crown Bioscience Inc.

Authors' contributions: Y Liu, X Wang, B Wang and G Sun conducted the study. Y Liu, F Gregoire, K Chng, J Wang, Y (Jim) Wang and Y-F Xiao participated study design and manuscript preparation.

\section{Acknowledgements}

Part of the data were presented at 2015 ADA conference and published in abstract format. We are grateful to our animal center for their professional care of the animals and excellent technical assistances during the study.

\section{References}

1. Shaw JE, Sicree RA, Zimmet PZ (2010) Global estimates of the prevalence of diabetes for 2010 and 2030. Diabetes Res Clin Pract 87: 4-14.

2. Teta M, Rankin MM, Long SY, Stein GM, Kushner JA (2007) Growth and regeneration of adult beta cells does not involve specialized progenitors. Dev Cell 12: 817-826.

3. Xu X, D'Hoker J, Stange G, Bonne S, De Leu N, et al. (2008) Beta cells can be generated from endogenous progenitors in injured adult mouse pancreas. Cell 132: 197-207.

4. Collombat P, Xu X, Ravassard P, Sosa-Pineda B, Dussaud S, et al. (2009) The ectopic expression of Pax4 in the mouse pancreas converts progenitor cells into alpha and subsequently beta cells. Cell 138: 449-462.

5. Butler AE, Cao-Minh L, Galasso R, Rizza RA, Corradin A, et al. (2010) Adaptive changes in pancreatic beta cell fractional area and beta cell turnover in human pregnancy. Diabetologia 53: 2167-2176.

6. Van Assche FA, Aerts L, De Prins F (1978) A morphological study of the endocrine pancreas in human pregnancy. Br J Obstet Gynaecol 85: 818-820.

7. Karnik SK, Chen H, McLean GW, Heit JJ, Gu X, et al. (2007) Menin controls growth of pancreatic beta-cells in pregnant mice and promotes gestational diabetes mellitus. Science 318: 806-809.

8. Quagliarini F, Wang Y, Kozlitina J, Grishin NV, Hyde R, et al. (2012) Atypical angiopoietin-like protein that regulates ANGPTL3. Proc Natl Acad Sci U S A 109: $19751-19756$

9. Zhang R (2012) Lipasin, a novel nutritionally-regulated liver-enriched factor that regulates serum triglyceride levels. Biochem Biophys Res Commun 424: 786-792.

10. Fu Z, Yao F, Abou-Samra AB, Zhang R (2013) Lipasin, thermoregulated in brown fat, is a novel but atypical member of the angiopoietin-like protein family. Biochem Biophys Res Commun 430: 1126-1131.

11. Zhang R, Abou-Samra AB (2014) A dual role of lipasin (betatrophin) in lipid metabolism and glucose homeostasis: consensus and controversy. Cardiovasc Diabetol 13:133.

12. Yi P, Park JS, Melton DA (2013) Betatrophin: a hormone that controls pancreatic beta cell proliferation. Cell 153: 747-758.

13. Tseng YH, Yeh YH, Chen WJ, Lin KH (2014) Emerging regulation and function of betatrophin. Int J Mol Sci 15: 23640-23657.

14. Raghow R (2014) Betatrophin: A liver-derived hormone for the pancreatic betacell proliferation. World J Diabetes 4: 234-237.

15. Lickert H (2013) Betatrophin fuels beta cell proliferation: first step toward regenerative therapy? Cell Metab 18: 5-6.

16. Cox AR, Lam CJ, Bonnyman CW, Chavez J, Rios JS, et al. (2015) Angiopoietinlike protein 8 (ANGPTL8)/betatrophin overexpression does not increase beta cell proliferation in mice. Diabetologia 58: 1523-1531.

17. Cox AR, Barrandon O, Cai EP, Rios JS, Chavez J, et al. (2016) Resolving Discrepant Findings on ANGPTL8 in $\beta$-Cell Proliferation: A Collaborative Approach to Resolving the Betatrophin Controversy. PLoS One 11: e0159276. 24

18. Gusarova V, Alexa CA, Na E, Stevis PE, Xin Y, et al. (2014) ANGPTL8/ betatrophin does not control pancreatic beta cell expansion. Cell 159: 691-696.

19. Espes D, Lau J, Carlsson PO (2013) Increased circulating levels of betatrophin in individuals with long-standing type 1 diabetes. Diabetologia 57: 50-53.

20. Espes D, Martinell M, Carlsson PO (2014) Increased circulating betatrophin concentrations in patients with type 2 diabetes. Int J Endocrinol :323407.

21. Hu H, Sun W, Yu S, Hong X, Qian W, et al. (2014) Increased circulating levels of betatrophin in newly diagnosed type 2 diabetic patients. Diabetes Care 37 : 2718-2722.

22. Chen X, Lu P, He W, Zhang J, Liu L, et al. (2014) Circulating betatrophin levels are increased in patients with type 2 diabetes and associated with insulin resistance. J Clin Endocrinol Metab 100: E96-E100.

23. Yamada H, Saito T, Aoki A, Asano T, Yoshida M, et al. (2015) Circulating betatrophin is elevated in patients with type 1 and type 2 diabetes. Endocr $\mathrm{J}$ 62: $417-421$

24. Trebotic LK, Klimek P, Thomas A, Fenzl A, Leitner K, et al.(2015) Circulating Betatrophin Is Strongly Increased in Pregnancy and Gestational Diabetes Mellitus 10: e0136701.

25. Brissova M, Fowler MJ, Nicholson WE, Chu A, Hirshberg B, et al. (2005) Assessment of human pancreatic islet architecture and composition by laser scanning confocal microscopy. J Histochem Cytochem 53: 1087-1097.

26. Cabrera O, Berman DM, Kenyon NS, Ricordi C, Berggren PO, et al. (2006) The unique cytoarchitecture of human pancreatic islets has implications for islet cell function. Proc Natl Acad Sci USA 103: 2334-2339.

27. Bosco D, Armanet M, Morel P, Niclauss N, Sgroi A, et al. (2010) Unique arrangement of alpha- and beta-cells in human islets of Langerhans. Diabetes 59: $1202-1210$.

28. Zou C, Wang J, Wang S, Huang F, Ren Z, et al. (2012) Characterizing the induction of diabetes in juvenile cynomolgus monkeys with different doses of streptozotocin. Sci China Life Sci 55: 210-218.

29. Pitkin RM, Reynolds WA (1970) Diabetogenic effects of streptozotocin in rhesus monkeys. Diabetes 19: 85-90.

30. Litwak KN, Cefalu WT, Wagner JD (1998) Streptozotocin-induced diabetes mellitus in cynomolgus monkeys: changes in carbohydrate metabolism, skin glycation, and pancreatic islets. Lab Anim Sci 48: 172-178. 
Citation: Yongqiang Liu, Xiaoli Wang, Bingdi Wang, Guofeng Sun, Francine Gregoire, et al. (2016) Dynamic Changes of Betatrophin and Its Potential Effect on $\beta$-cells in Spontaneously Developed or Streptozocin-induced Diabetes Monkeys. J Diabetes Metab 7: 719. doi: $10.4172 / 2155-6156.1000719$

Page 10 of 10

31. Thomas JM, Contreras JL, Smyth CA, Lobashevsky A, Jenkins S, et al. (2001) Successful reversal of streptozotocin-induced diabetes with stable allogeneic islet function in a preclinical model of type 1 diabetes. Diabetes 50: 1227-1236.

32. Kavanagh K, Flynn DM, Nelson C, Zhang L, Wagner JD (2011) Characterization and validation of a streptozotocin-induced diabetes model in the vervet monkey. J Pharmacol Toxicol Methods 63: 296-303.

33. Hansen BC (2012) Investigation and treatment of type 2 diabetes in nonhuman primates. Methods Mol Biol 933: 177-185.

34. Hansen BC, Bodkin NL (1993) Standardization of IVGTT. Importance of method used to calculate glucose disappearance. Diabetes care 16: 847.

35. Koulmanda M, Qipo A, Chebrolu S, O'Neil J, Auchincloss H, et al. (2003) The effect of low versus high dose of streptozotocin in cynomolgus monkeys (Macaca fascilularis). Am J Transplant 3: 267-272.

36. Michael MD, Kulkarni RN, Postic C, Previs SF, Shulman GI, et al. (2000) Loss of insulin signaling in hepatocytes leads to severe insulin resistance and progressive hepatic dysfunction. Mol Cell 6: 87-97.

37. Gao T, Jin K, Chen $\mathrm{P}$, Jin $\mathrm{H}$, Yang $\mathrm{L}$, et al. (2015) Circulating Betatrophin Correlates with Triglycerides and Postprandial Glucose among Different Glucose Tolerance Statuses-A Case-Control Study. PLoS One 10: e0133640.

38. Ghasemi H, Tavilani H, Khodadadi I, Saidijam M, Karimi J (2016) Circulating Betatrophin Levels Are Associated with the Lipid Profile in Type 2 Diabetes. Chonnam Med J 51: 115-119.

39. Li S, Liu D, Li L, Li Y, Li Q, et al. (2016) Circulating Betatrophin in Patients with Type 2 Diabetes: A Meta-Analysis. J Diabetes Res.

40. Tokumoto S, Hamamoto Y, Fujimoto K, Yamaguchi E, Okamura E, et al. (2015) Correlation of circulating betatrophin concentrations with insulin secretion capacity, evaluated by glucagon stimulation tests. Diabet Med 32: 653-656.

41. Wang L, Song J, Wang C, Lin P, Liang K, et al. (2015) Circulating Levels of Betatrophin and Irisin Are Not Associated with Pancreatic beta-Cell Function in Previously Diagnosed Type 2 Diabetes Mellitus Patients. J Diabetes Res.

42. Jiao Y, Le Lay J, Yu M, Naji A, Kaestner KH (2013) Elevated mouse hepatic betatrophin expression does not increase human beta-cell replication in the transplant setting. Diabetes 63: 1283-1288.

43. Zhang R, Abou-Samra AB (2013) Emerging roles of Lipasin as a critical lipid regulator. Biochem Biophys Res Commun 432: 401-405.
44. Abu-Farha M, Sriraman D, Cherian P, AlKhairi I, Elkum N, et al. (2016) Circulating ANGPTL8/Betatrophin Is Increased in Obesity and Reduced after Exercise Training. Plos One 11: e0147367.

45. Schnedl WJ, Ferber S, Johnson JH, Newgard CB (1994) STZ transport and cytotoxicity. Specific enhancement in GLUT2-expressing cells. Diabetes 43 1326-1333.

46. Wang Z, Gleichmann H (1998) GLUT2 in pancreatic islets: crucial targe molecule in diabetes induced with multiple low doses of streptozotocin in mice. Diabetes 47: 50-56.

47. Brentjens R, Saltz L (2001) Islet cell tumors of the pancreas: the medica oncologist's perspective. Surg Clin North Am 81: 527-542.

48. Nir T, Melton DA, Dor $Y$ (2007) Recovery from diabetes in mice by beta cel regeneration. J Clin Invest 117: 2553-2561.

49. Alonso LC, Yokoe T, Zhang P, Scott DK, Kim SK, et al. (2007) Glucose infusion in mice: a new model to induce beta-cell replication. Diabetes 56: 1792-1801.

50. Xu G, Stoffers DA, Habener JF, Bonner-Weir S (1999) Exendin-4 stimulates both beta-cell replication and neogenesis, resulting in increased beta-cell mass and improved glucose tolerance in diabetic rats. Diabetes 48: 2270-2276.

51. Bonner-Weir S, Li WC, Ouziel-Yahalom L, Guo L, Weir GC, et al. (2010) Betacell growth and regeneration: replication is only part of the story. Diabetes 59 : 2340-2348.

52. Zhang Y, Li R, Meng Y, Li S, Donelan W, et al. (2013) Irisin stimulates browning of white adipocytes through mitogen-activated protein kinase p38 MAP kinase and ERK MAP kinase signaling. Diabetes 63: 514-525.

53. Bonner-Weir S, Li WC, Ouziel-Yahalom L, Guo L, Weir GC, et al. (2010) Betacell growth and regeneration: replication is only part of the story. Diabetes 59 : 2340-2348.

54. Xie X, Gao T, Yang M, Chen P, Jin H, et al. (2015) Associations of betatrophin levels with irisin in Chinese women with normal glucose tolerance. Diabetology \& metabolic syndrome $7: 26$.

55. Sanchis-Gomar F, Perez-Quilis C (2014) The p38-PGC-1alpha-irisin-betatrophin axis: Exploring new pathways in insulin resistance. Adipocyte 3: 67-68. 